\title{
Bone mineral content in bronchopulmonary dysplasia
}

\author{
S RYAN,* P J CONGDON, ${ }^{*}$ A HORSMAN, $\dagger$ J R JAMES, ${ }^{*}$ J TRUSCOTT, $\dagger$ AND R ARTHUR* \\ ${ }^{*}$ Regional Neonatal Surgical and Intensive Care Unit and $\dagger M R C$ Mineral Metabolism Unit, General \\ Infirmary, Leeds
}

SUMMARY Fourteen preterm infants who developed bronchopulmonary dysplasia diagnosed radiologically were compared with a group of similar infants who did not. The two groups were of comparable maturity and birth weight. The clinical histories indicated that those infants with bronchopulmonary dysplasia had had longer periods of supplemental oxygen, more frequent treatment with dexamethasone, and a higher mean total dosage of frusemide.

Bone mineral content in the mid-forearm was measured by photon absorptiometry at or near the postconceptional age of 40 weeks in all cases; no significant difference was found between the two groups, although both were severely undermineralised when compared with infants born at full term. In both groups mean daily calcium intake (about $70 \mathrm{mg} / \mathrm{kg} / \mathrm{day}$ ) was about half the daily intrauterine accretion of calcium.

Impaired skeletal mineral absorption is common in preterm infants after prolonged intensive care. ${ }^{1}$ In such cases the deficit in bone mineral content (BMC) can be measured accurately by photon absorptiometry, ${ }^{2}$ and we have shown that at a postconceptional age of 40 weeks the deficit in BMC in the mid-forearm compared with that in the arms of full term infants measured at birth is about $20 \%$. $^{34}$

Inability in postnatal life to match intrauterine skeletal mineral absorption may be exacerbated by several factors including prolonged intravenous nutrition with its inherent limitation on mineral intake $^{5}$; fluid restriction, resulting in decreased intake of calcium and phosphorus; physiological losses of calcium and phosphorus in stool and urine, which limit the quantities retained; chronic acidosis $^{6} ;$ and treatment with steroids ${ }^{7}$ and diuretics. ${ }^{8}$ These factors are more common in infants undergoing prolonged intensive care, who often develop bronchopulmonary dysplasia (BPD).

Although there have been reports of radiologically diagnosed bone disease occurring in conjunction with chronic neonatal lung disease, ${ }^{910}$ only once to our knowledge has its severity been measured by photon absorptiometry. ${ }^{11}$ As part of a larger study of bone mineral absoption in neonates we compared otherwise similar groups of preterm infants with and without BPD to ascertain whether undermineralisation was more severe in those with BPD.

\section{Patients and methods}

This retrospective study was confined to infants who had undergone photon absorptiometry of the forearm at or near the postconceptional age of 40 weeks. Informed consent was obtained from the parents and the study approved by the hospital ethical committee.

Over a period of 26 months 14 infants who needed ventilation for hyaline membrane disease developed radiological and clinical evidence of BPD. Using established criteria, ${ }^{12}$ a paediatric radiologist (RA) graded their chest radiographs as showing either moderate or severe BPD. Fourteen infants of similar maturity and birth weight who were in the unit during the same period were identified and formed the control group; they were selected because they too had been ventilated but their chest radiographs showed either mild or no changes of BPD. Table 1 shows the sex, gestational age, birth weight, and duration of stay in the unit of each infant.

The number of days of ventilation and the number of days of supplemental oxygen were recorded for each infant. Table 2 gives these details together with the number of days of intravenous fluid replacement, acidosis (blood $\mathrm{pH}$ less than $7 \cdot 30$, usually respiratory in origin), and treatment with dexamethasone $(0 \cdot 1 \mathrm{mg} / \mathrm{kg} / \mathrm{dose})$ when these data were available. Only one infant in the control group 
Table 1 Clinical details of infants studied

\begin{tabular}{|c|c|c|c|c|}
\hline $\begin{array}{l}\text { Case } \\
\text { No }\end{array}$ & Sex & $\begin{array}{l}\text { Gestational } \\
\text { age } \\
\text { (weeks) }\end{array}$ & $\begin{array}{l}\text { Birth } \\
\text { weight } \\
(g)\end{array}$ & $\begin{array}{l}\text { Stay in } \\
\text { unit } \\
\text { (days) }\end{array}$ \\
\hline \multicolumn{5}{|c|}{ Group with BPD } \\
\hline 1 & $F$ & 26 & 725 & 94 \\
\hline 2 & $\mathrm{~F}$ & 26 & 950 & 98 \\
\hline 3 & M & 26 & 1010 & 84 \\
\hline 4 & $\mathrm{M}$ & 26 & 1020 & 78 \\
\hline 5 & $F$ & 27 & 780 & 72 \\
\hline 6 & $F$ & 27 & 1125 & 91 \\
\hline 7 & M & 27 & 740 & 70 \\
\hline 8 & M & 27 & 1300 & 77 \\
\hline 9 & $\mathbf{M}$ & 28 & 1000 & 60 \\
\hline 10 & M & 28 & 1000 & 55 \\
\hline 11 & $\mathbf{F}$ & 29 & 1200 & 98 \\
\hline 12 & $\mathbf{M}$ & 29 & 1550 & 105 \\
\hline 13 & $\mathbf{M}$ & 30 & 1300 & 82 \\
\hline 14 & $\mathbf{M}$ & 30 & 1770 & 70 \\
\hline Mean & & $27 \cdot 57$ & 1105 & $81 \cdot 0$ \\
\hline $\mathrm{SD}$ & & 1.45 & 300 & $14 \cdot 9$ \\
\hline $\mathrm{SE}$ & & 0.39 & 80 & $4 \cdot 0$ \\
\hline \multicolumn{5}{|c|}{ Control group } \\
\hline 15 & $\mathbf{F}$ & 26 & 840 & 80 \\
\hline 16 & $\mathbf{M}$ & 26 & 900 & 70 \\
\hline 17 & M & 27 & 725 & 65 \\
\hline 18 & $\mathbf{M}$ & 27 & 1000 & 91 \\
\hline 19 & $\mathrm{~F}$ & 28 & 1150 & 32 \\
\hline 20 & $F$ & 28 & 1500 & 84 \\
\hline 21 & $\mathrm{M}$ & 28 & 1250 & 84 \\
\hline 22 & $\mathrm{M}$ & 28 & 1300 & 63 \\
\hline 23 & M & 28 & 1350 & 64 \\
\hline 24 & $\mathbf{M}$ & 28 & 1450 & 38 \\
\hline 25 & $\mathrm{~F}$ & 29 & 1400 & 77 \\
\hline 26 & $\mathrm{~F}$ & 30 & 800 & 54 \\
\hline 27 & $\mathrm{~F}$ & 31 & 1100 & 52 \\
\hline 28 & $\mathbf{M}$ & 31 & 1400 & 51 \\
\hline Mean & & $28 \cdot 21$ & 1155 & $64 \cdot 6$ \\
\hline $\mathrm{SD}$ & & $1 \cdot 58$ & 263 & $17 \cdot 8$ \\
\hline SE & & 0.42 & 70 & $4 \cdot 7$ \\
\hline
\end{tabular}

received dexamethasone (for laryngeal oedema). Table 3 shows the number of doses of frusemide $(1-2 \mathrm{mg} / \mathrm{kg})$ given to each infant; treatment with dexamethasone or frusemide, or both, was always stopped before discharge from the unit.

Oral fluid intake was used to derive energy and mineral intakes from manufacturers' data sheets. Table 3 lists the total calcium intake with corresponding mean daily intakes of fluid, energy, and calcium up to the day when photon absorptiometry was performed. Fluid intake was unknown in two cases.

We always supplement the milk with vitamin D (400 or 1000 IU daily) once oral feeds can be tolerated, and vitamin D intake is usually recorded throughout each infant's stay in the unit; the mean daily intake over the period up to discharge was calculated for each infant and is also shown in table 3. No attempt was made to estimate vitamin D intake after discharge from the unit. Data were not available in three cases.

BMC in the mid-forearm was measured as previously described. ${ }^{2}{ }^{4}$ Photon absorptiometry of the forearm in neonates entails a small skin entrance dose of $0.03 \mathrm{mGy}$ ( 3 mrads) for each investigation; a $0.5 \mathrm{~cm}$ length of forearm is irradiated. The procedure was done in 24 of the infants at postconceptional ages ranging from 37 to 41 weeks, and the remaining four within six days of these limits. Results are expressed as mass of ash per unit length $(\mathrm{mg} / \mathrm{cm})$. Crown-heel length $(\mathrm{cm})$, weight $(\mathrm{g})$, and ulnar length $(\mathrm{mm})$ were measured when photon absorptiometry was performed. Table 4 shows the results of the radiological grading for evidence of $\mathrm{BPD}$, the results of photon absorptiometry, and anthropometric data. Blood samples were taken for assay of plasma concentrations of 25-hydroxyvitamin $\mathrm{D}$ from 18 of the 28 infants on the day that absorptiometry was performed. ${ }^{13}$ These results are also shown in table 4 .

When the data were normally distributed the mean, standard deviation (SD), and standard error (SE) of each measurement were computed for each group and the significance of the difference between the two group means calculated with the unpaired Student's $t$ test. Otherwise only the means were calculated and a non-parametric test (MannWhitney U test or Wilcoxon rank sum test) used to calculate the significance of the differences between the two groups. Two tailed probabilities are quoted throughout.

\section{Results}

There were no significant differences in mean gestational age or birth weight between the infants with BPD and the controls (Table 1). Those with BPD spent significantly more time in the unit $(p<0.02$; table 1$)$ and required more days of ventilation $(p<0.001)$ and supplemental oxygen $(p<0.001$; table 2$)$ than the controls. Intravenous fluid replacement was undertaken significantly more often $(p<0.01)$ and acidosis occurred more frequently $(p<0.005)$ in the group with BPD than in the control group. Infants with BPD were treated more frequently with dexamethasone $(\mathrm{p}<0.005$; table 2); the mean total frusemide dosage was also significantly higher $(p<0.05$; table 3$)$.

The mean total calcium intake was significantly lower in the group with BPD than in the control group (6.46 g $v 10.33 \mathrm{~g} ; \mathrm{p}<0.05$; table 3$)$. The mean daily calcium intake in the group with BPD 
Table 2 Number of days of ventilation, supplementary oxygen, intravenous fluid replacement, acidosis, and treatment with dexamethasone therapy

\begin{tabular}{|c|c|c|c|c|c|}
\hline Case No & Ventilation & Oxygen & Fluids & Acidosis & Dexamethasone \\
\hline \multicolumn{6}{|c|}{ Group with BFD } \\
\hline 1 & 32 & 84 & 45 & 22 & 24 \\
\hline 2 & 23 & 65 & 30 & 29 & 30 \\
\hline 3 & 49 & 98 & 38 & 37 & 9 \\
\hline 4 & 20 & 56 & 19 & 15 & 11 \\
\hline 5 & 17 & 28 & 34 & 15 & 9 \\
\hline 6 & 24 & 27 & 32 & 13 & 0 \\
\hline 7 & 26 & 88 & 42 & 18 & 0 \\
\hline 8 & 12 & 22 & 41 & 8 & 22 \\
\hline 9 & 31 & 20 & - & - & - \\
\hline 10 & 22 & 85 & 40 & 30 & 8 \\
\hline 11 & 21 & 26 & 24 & 10 & 31 \\
\hline 12 & 37 & 36 & 38 & 14 & 0 \\
\hline 13 & 18 & 36 & 29 & 14 & 38 \\
\hline 14 & 37 & 69 & 44 & 14 & 7 \\
\hline Mean & $26 \cdot 4$ & $52 \cdot 9$ & $35 \cdot 1$ & $18 \cdot 4$ & $14 \cdot 5$ \\
\hline \multicolumn{6}{|c|}{ Control group } \\
\hline 15 & 22 & 29 & 43 & 15 & 0 \\
\hline 16 & 5 & 27 & 7 & 7 & 0 \\
\hline 17 & 1 & 1 & 3 & 4 & 0 \\
\hline 18 & 18 & 43 & 32 & - & 6 \\
\hline 19 & 4 & 5 & 6 & 3 & 0 \\
\hline 20 & 26 & 21 & 33 & 22 & 0 \\
\hline 21 & 22 & 26 & 61 & 12 & 0 \\
\hline 22 & 8 & 9 & 14 & 8 & 0 \\
\hline 23 & 14 & 16 & 17 & 5 & 0 \\
\hline 24 & 7 & 10 & 9 & 5 & - \\
\hline 25 & 7 & 19 & 9 & 9 & 0 \\
\hline 26 & 1 & 1 & 2 & 1 & 0 \\
\hline 27 & 7 & 7 & 9 & 7 & 0 \\
\hline 28 & 14 & 17 & 17 & 6 & 0 \\
\hline Mean & $11 \cdot 1$ & $16 \cdot 5$ & $18 \cdot 7$ & 8.0 & 0.5 \\
\hline
\end{tabular}

(expressed as $\mathrm{mmol} / \mathrm{kg} / \mathrm{day}$ ) was also lower but not significantly so. Daily fluid and energy intakes were significantly lower in the group with BPD than in the control group $(p<0.02$ and $p<0.05$, respectively).

The group with BPD had a lower mean vitamin D intake than the control group (306 v 472 IU daily); this difference was significant $(\mathrm{p}<0.05)$. The mean plasma 25-hydroxyvitamin $\mathrm{D}$ concentrations around the postconceptional age of 40 weeks were comparable and not significantly different between the two groups; in the group with BPD one infant had a value below $25 \mathrm{nmol} / \mathrm{l}$ whereas four controls had values below that limit.

At about 40 weeks the infants with BPD were on average lighter than the controls (table 4); the difference (about $430 \mathrm{~g}$ ) between the group means was significant $(p<0.05)$. There were no significant differences between the two groups in mean crownheel length, ulnar length, or BMC. Even when the extreme cases were contrasted the mean BMC did not differ significantly between those with and without BPD; mean (SE) BMC in nine infants classified as having severe radiological changes associated with BPD was $98.0(5.5) \mathrm{mg} / \mathrm{cm}$, and in 10 controls with no radiological evidence of BPD the corresponding value was $105 \cdot 1 \quad(11.4) \mathrm{mg} / \mathrm{cm}$. Although significant differences between groups could not be shown, the mean BMC was only about $100 \mathrm{mg} / \mathrm{cm}$ in both the BPD and control groups; in contrast, the mean value in full term infants measured at birth with the same apparatus has been shown to be $194.0(3.7) \mathrm{mg} / \mathrm{cm}^{4}$

\section{Discussion}

During pregnancy the placenta provides the fetus with a readily available source of calcium and phosphorus. It has been estimated that the accretion of calcium in utero is about $130 \mathrm{mg} / \mathrm{kg} /$ day during 
Table 3 Total number of doses of frusemide and intake of calcium and average daily intake of fluid, energy, calcium, and vitamin $D$

\begin{tabular}{|c|c|c|c|c|c|c|}
\hline \multirow{2}{*}{$\begin{array}{l}\text { Case } \\
\text { No }\end{array}$} & \multicolumn{2}{|c|}{ Total intake } & \multicolumn{4}{|c|}{ Daily intake } \\
\hline & $\begin{array}{l}\text { Frusemide } \\
\text { (No of } \\
\text { doses) }\end{array}$ & $\begin{array}{l}\text { Calcium } \\
\text { (g) }\end{array}$ & $\begin{array}{l}\text { Fluid } \\
\text { (mlikg) }\end{array}$ & $\begin{array}{l}\text { Energy } \\
(\mathrm{kJ} / \mathrm{kg})\end{array}$ & $\begin{array}{l}\text { Calcium } \\
\text { (mmol/kg) }\end{array}$ & $\begin{array}{l}\text { Vitamin D } \\
(I U)\end{array}$ \\
\hline \multicolumn{7}{|c|}{ Group with BPD } \\
\hline 1 & 22 & $5 \cdot 72$ & 172 & & $1 \cdot 17$ & 252 \\
\hline 2 & 8 & $5 \cdot 34$ & 152 & $26 \cdot 0$ & $2 \cdot 62$ & 230 \\
\hline 3 & 109 & $9 \cdot 55$ & 160 & $22 \cdot 9$ & 1.92 & 176 \\
\hline 4 & 29 & & 1.37 & & & 853 \\
\hline 5 & 7 & $3 \cdot 65$ & 1.57 & $20 \cdot 3$ & $1 \cdot 14$ & 453 \\
\hline 6 & 7 & $3 \cdot 86$ & 149 & $17 \cdot 7$ & $1 \cdot 15$ & 582 \\
\hline 7 & 50 & $7 \cdot 49$ & 140 & $20 \cdot 6$ & $1 \cdot 50$ & 213 \\
\hline 8 & () & $8 \cdot 96$ & 1.38 & $19 \cdot()$ & $1 \cdot 71$ & 220 \\
\hline 9 & & $8 \cdot 60$ & 1.32 & 19.9 & $1 \cdot 86$ & \\
\hline 10 & 60 & $4 \cdot 44$ & 1.37 & & $2 \cdot 34$ & 195 \\
\hline 11 & 2 & & & & & \\
\hline 12 & 49 & $12 \cdot 93$ & 1.35 & 19.9 & $1 \cdot 81$ & 143 \\
\hline 13 & () & $1 \cdot 38$ & 133 & $15 \cdot 5$ & 0.99 & 281 \\
\hline 14 & 114 & $5 \cdot 60$ & 134 & $17 \cdot 7$ & $1 \cdot 40$ & 77 \\
\hline Mean & $35 \cdot 2$ & $6 \cdot 46$ & $144 \cdot 3$ & $20 \cdot()$ & $1 \cdot 63$ & 306 \\
\hline SD & & & $12 \cdot 6$ & $2 \cdot 9$ & $(0.51$ & \\
\hline SE & & & $3 \cdot 5$ & 0.9 & $(1) \cdot 15$ & \\
\hline \multicolumn{7}{|c|}{ Control group } \\
\hline 15 & 11 & $14 \cdot 45$ & 143 & $23 \cdot 7$ & $1 \cdot 81$ & 475 \\
\hline 16 & 1 & $13 \cdot 92$ & 165 & $26 \cdot()$ & $2 \cdot 14$ & 478 \\
\hline 17 & () & $7 \cdot 63$ & 219 & $33 \cdot 7$ & $3 \cdot 16$ & 384 \\
\hline 18 & & $9 \cdot 23$ & 157 & $19 \cdot 6$ & $1 \cdot 78$ & 618 \\
\hline 19 & () & $7 \cdot 24$ & 167 & $27 \cdot 5$ & $1 \cdot 26$ & 911 \\
\hline 20 & 28 & $9 \cdot 31$ & 165 & $21 \cdot 8$ & $1 \cdot 75$ & 552 \\
\hline 21 & 4 & $3 \cdot 42$ & 140 & $14 \cdot 1$ & $(0.79$ & 97 \\
\hline 22 & () & $13 \cdot 33$ & 167 & $29 \cdot 9$ & $2 \cdot 10$ & 374 \\
\hline 23 & 6 & $11 \cdot 86$ & 139 & $20 \cdot 5$ & $1 \cdot 88$ & 490 \\
\hline 24 & 21 & 11.96 & 139 & $22 \cdot 4$ & $1 \cdot 90$ & 424 \\
\hline 25 & 9 & & & & & \\
\hline 26 & 0 & $15 \cdot 48$ & 187 & $31 \cdot 3$ & $2 \cdot 66$ & 464 \\
\hline 27 & 3 & $6 \cdot 11$ & 165 & $26 \cdot 4$ & $1 \cdot 41$ & 592 \\
\hline 28 & 6 & $10 \cdot 35$ & 153 & $22 \cdot 4$ & $1 \cdot 77$ & 273 \\
\hline Mean & $6 \cdot 8$ & $10 \cdot 33$ & $162 \cdot 0$ & $24 \cdot 6$ & $1 \cdot 88$ & 472 \\
\hline SD & & & $22 \cdot 3$ & $5 \cdot 3$ & 0.59 & \\
\hline SE & & & $6 \cdot 2$ & 1.5 & $(0 \cdot 16$ & \\
\hline
\end{tabular}

the last trimester of pregnancy, resulting in the deposition of about $25 \mathrm{~g}$ of calcium in the fetal skeleton. ${ }^{14}$ Because many premature infants have nutritional problems it is not surprising that inadequate skeletal mineral absorption is common. Although skeletal changes associated with neonatal bone disease can sometimes be detected radiologically, ${ }^{15}$ the more sensitive technique of photon absorptiometry has shown that the bones of almost all premature infants are deficient in minerals by the time they reach the postconceptional age of 40 weeks. ${ }^{34}$

There are compelling theoretical reasons for believing that inadequate skeletal mineralisation should be more pronounced in infants who develop BPD. As we have shown, these infants are generally more ill and require longer periods of ventilation and supplemental oxygen with restriction of fluids, and hence lower calcium and phosphorus intakes. Although we did not attempt to carry out balance studies, in both the BPD and control groups the average daily calcium intake over the study period was far less than would be expected in utero. Furthermore, the calcium available for absorption into bone was considerably less than the intake because retention was probably no more than $50 \% .{ }^{16}$ Calcium retention in the group with BPD was probably further reduced by treatment with 
Table 4 Observations at postconceptional age of 40 weeks

\begin{tabular}{|c|c|c|c|c|c|c|}
\hline Case No & $\begin{array}{l}\text { Radiological } \\
\text { grade* }^{*}\end{array}$ & $\begin{array}{l}\text { Weight } \\
\text { (g) }\end{array}$ & $\begin{array}{l}\text { Crown-heel } \\
\text { length } \\
(\mathrm{cm})\end{array}$ & $\begin{array}{l}\text { Ulnar } \\
\text { length } \\
(\mathrm{mm})\end{array}$ & $\begin{array}{l}B M C \\
(\mathrm{mg} / \mathrm{cm})\end{array}$ & $\begin{array}{l}\text { 25-Hydroxy } \\
\text { vitamin } D \\
\text { (nmol/l) }\end{array}$ \\
\hline \multicolumn{7}{|c|}{ Group with BPD } \\
\hline 1 & 3 & 1775 & 4()$\cdot 2$ & $57 \cdot 5$ & $94 \cdot 1$ & \\
\hline 2 & 3 & 2170 & $44 \cdot 3$ & $64 \cdot 0$ & $86 \cdot 3$ & \\
\hline 3 & 3 & 1980 & $40 \cdot 6$ & $67 \cdot 0$ & $121 \cdot 4$ & 198 \\
\hline 5 & 3 & 2570 & $45 \cdot 5$ & $73 \cdot 0$ & $66 \cdot 0$ & \\
\hline 6 & 3 & 1400 & $40 \cdot 2$ & $61 \cdot 0$ & $111 \cdot 8$ & 58 \\
\hline 7 & 3 & 1620 & $39 \cdot 5$ & $61 \cdot 0$ & $89 \cdot 2$ & \\
\hline 8 & 2 & 1990 & $43 \cdot 5$ & $69 \cdot 0$ & $101 \cdot 1$ & 113 \\
\hline 9 & 3 & 1900 & $40 \cdot 9$ & $66 \cdot 0$ & $102 \cdot 3$ & \\
\hline 10 & 3 & 1400 & $39 \cdot 1$ & $56 \cdot 3$ & $109 \cdot 2$ & \\
\hline 11 & 2 & 1650 & $42 \cdot 1$ & $63 \cdot 0$ & $96 \cdot 7$ & 69 \\
\hline 12 & 2 & 2650 & $46 \cdot 9$ & $73 \cdot 0$ & $129 \cdot 7$ & 8 \\
\hline 14 & 3 & 1450 & $43 \cdot 8$ & $60 \cdot 0$ & $101 \cdot 3$ & 25 \\
\hline Mean & & 1935 & $42 \cdot 39$ & $64 \cdot 77$ & $99 \cdot 86$ & 84 \\
\hline $\mathrm{SD}$ & & 446 & $2 \cdot 41$ & $5 \cdot 28$ & $15 \cdot 57$ & \\
\hline SE & & 119 & 0.64 & $1 \cdot 41$ & $4 \cdot 16$ & \\
\hline \multicolumn{7}{|c|}{ Control group } \\
\hline 15 & 0 & 2520 & $46 \cdot 0$ & $72 \cdot 5$ & $79 \cdot 6$ & \\
\hline 16 & 0 & 3000 & $41 \cdot 5$ & $67 \cdot 0$ & $126 \cdot 1$ & 82 \\
\hline 17 & 0 & 1600 & $40 \cdot 0$ & $58 \cdot 0$ & $65 \cdot 0$ & 4 \\
\hline 18 & 1 & 1840 & $40 \cdot 5$ & $60 \cdot 5$ & $90 \cdot 4$ & \\
\hline 19 & 0 & 2730 & $45 \cdot 1$ & $75 \cdot 0$ & $100 \cdot 2$ & 107 \\
\hline 20 & 1 & 1650 & $40 \cdot 2$ & $64 \cdot 0$ & $87 \cdot 5$ & 23 \\
\hline 21 & 1 & 1520 & $40 \cdot()$ & $62 \cdot 0$ & $79 \cdot 3$ & 18 \\
\hline 22 & 1 & 2500 & $45 \cdot 0$ & $69 \cdot 0$ & $104 \cdot 7$ & 15 \\
\hline 23 & 0 & 2800 & $47 \cdot 5$ & $74 \cdot 0$ & $127 \cdot 5$ & 201 \\
\hline 24 & 0 & 3450 & $50 \cdot 8$ & $85 \cdot 0$ & $124 \cdot 0$ & \\
\hline 27 & 0 & 1800 & $42 \cdot 0$ & $65 \cdot 0$ & $82 \cdot 9$ & 105 \\
\hline 28 & 0 & 2780 & $48 \cdot 2$ & $75 \cdot 0$ & $183 \cdot 5$ & 131 \\
\hline Mean & & 2362 & $44 \cdot(1) 8$ & $69 \cdot 18$ & $100 \cdot 90$ & 76 \\
\hline SD & & 599 & 3.45 & $7 \cdot 15$ & $31 \cdot 17$ & \\
\hline SE & & 160 & 0.92 & 1.91 & $8 \cdot 33$ & \\
\hline
\end{tabular}

${ }^{*} 0=$ normal, $1=$ mild, $2=$ moderate, $3=$ severe $\mathrm{BPD}$.

frusemide, which is known to increase urinary calcium excretions. ${ }^{8}$ Additionally, because steroids cause a reduction in the mineral content of bone in adults, it might be expected that treatment with dexamethasone would also have deleterious effects on the infant skeleton.?

Despite these expectations we did not detect a difference in BMC of the forearm between the BPD and control groups using the most sensitive technique available. When compared with full term infants at birth the preterm infants with BPD observed at 40 weeks were severely deficient in minerals, but this seems to be a consequence of their prematurity and not a secondary effect of treatment. Greer and McCormick reached a similar conclusion, even though their controls were on average more mature and heavier than our infants with BPD. ${ }^{11}$

Though inadequate intake of both calcium and phosphorus is likely to be a major cause of mineral deficiency in preterm infants, ${ }^{17}$ vitamin D deficiency is also associated with bone disease.$^{18}$ Although the babies in our study ultimately received the recommended intake of $400 \mathrm{IU} /$ day, this could not be achieved until oral feeds were tolerated in sufficient quantities. Some infants received more vitamin D than is recommended (Table 3), and in some cases when enteral feeding was delayed the daily average intake over the period of stay in the neonatal unit was well below the recommended value. Although plasma 25-hydroxyvitamin D concentrations were 
similar in the two groups at the time that BMC was measured, when vitamin D intake was most likely to be optimal, those concentrations might not reflect earlier vitamin D state. Several infants had 25hydroxyvitamin $\mathrm{D}$ values below the concentration regarded as indicating vitamin $\mathrm{D}$ deficiency $(25$ $\mathrm{nmol} / \mathrm{l}$ ). Within this set of data, however, no significant association between the plasma 25hydroxyvitamin D concentrations and BMC could be shown.

The results of this study indicate that the skeleton is deficient in minerals in infants with BPD as a consequence of their prematurity. That such infants were not found to be more severely undermineralised than preterm controls without BPD was surprising. Both mineral and vitamin D intakes in preterm infants may be suboptimal during their stay in the neonatal unit, and both factors probably contribute to the development of neonatal bone disease, although the grossly deficient mineral intake (compared with the intrauterine accretion) may be the more important. ${ }^{17}$ It is reassuring to know that the current treatment of BPD with frusemide and dexamethasone does not seem to be detrimental. ${ }^{19}$

JRJ has a research grant from the Yorkshire Regional Health Authority. SR is supported by an award from the special trustees of the General Infirmary, Leeds. We thank E B Mawer for performing the vitamin D assays.

\section{References}

' Kulkarni PB, Hall RT, Rhodes P, Sheehan M, Callenbach J, Germann D. Rickets in very-low-birthweight infants. $J$ Pediatr 1980;96:249-52.

2 James JR, Truscott J, Congdon PJ, Horsman A. Measurement of bone mineral content in the human fetus by photon absorptiometry. Early Hum Dev 1986:13:169-81.

${ }^{3}$ Minton SD, Steichen JJ, Tsang RC. Bone mineral content in term and preterm appropriate-for-gestational-age infants. J Pediatr 1979;95:1037-42.

4 James JR, Congdon PJ. Truscott J. Horsman A. Arthur R. Osteopenia of prematurity. Arch Dis Child 1986;61:871-6.
${ }^{5}$ Eggert LD. Rusho WJ. MacKay MW. Chan GM. Calcium and phosphorus compatibility in parenteral nutrition solutions for nconates. Am J Hosp Pharm 1982;39:49-53.

- Peacock M. Osteomalacia and rickets. In: Nordin BEC, ed. Metabolic bone and stone disease. Edinburgh: Churchill Livingstone, 1984:71-111.

7 Hahn TJ, Boisseau VC, Avioli LV. Effect of chronic corticosteroid administrtaion on diaphyseal and metaphyseal bone mass. J Clin Endocrinol Metab 1974:39:274-82.

* Glasier CM. Stoddard RA. Ackerman NB, McCurdy FA, Null DM, deLemos RA. Nephrolithiasis in infants: association with chronic frusemide therapy. Am J Roentgenol 1983;140: $107-8$.

"Burnard ED, Gratton-Smith P. Pickton-Warlow CG, Grauaug A. Pulmonary insufficiency in prematurity. Aust Paediatr J 1965:1:12-38.

10 Glasgow JFT, Thomas PS. Rachitic respiratory distress in small preterm infants. Arch Dis Child 1977;52:268-73.

11 Greer FR, McCormick A. Bone growth and low bone mineral content in very low birth weight premature infants. Pediatr Res 1986;20:925-8.

12 Toce SS, Farrell PM, Leavitt LA, Samuels DP, Edwards DK. Clinical and roentgenographic scoring systems for assessing bronchopulmonary dysplasia. Am J Dis Child 1984;138:581-5.

13 Mawer EB, Hann JT, Berry JL. Davies M. Vitamin D metabolism in patients intoxicated with ergocalciferol. Clin $S_{c i}$ 1985:68:135-41.

14 Forbes GB. Calcium accumulation by the human fetus. Pediatrics 1976:57:976-7.

15 Koo WWK, Gupta JM, Nayanar VV, Wilkinson M, Posen S. Skeletal changes in preterm infants. Arch Dis Child 1982;57: 447-52.

it Greer FR. Tsang RC. Calcium, phosphorus, magnesium and vitamin $D$ requirements for the preterm infant. In: Tsang $R C$, ed. Vitamin and mineral requirements in preterm infants. New York: Marcel Dekker, 1985:99-136.

17 Steichen JJ, Gratton TL. Tsang RC. Osteopenia of prematurity: the cause and possible treatment. J Pediatr 1980;96:249-52.

18 Cifuentes RF, Kooh S, Radde I. Vitamin D deficiency in a calcium supplemented very-low-birthweight infant. $J$ Pediatr 1980;96:252-5.

${ }^{19}$ O’Brodovich HM, Mellins RB. Bronchopulmonary dysplasia unresolved neonatal acute lung injury. Am Rev Respir Dis 1985:122:694-709.

Correspondence to Dr S Ryan, Regional Neonatal Surgical and Intensive Care Unit, Clarendon Wing, General Infirmary, Leeds LS2 9NS.

Received 29 April 1987 